\title{
Rage Against the Regime: Niche-regime interactions in the societal embedding of plant-based milk
}

DOI:

10.1016/j.eist.2018.11.001

\section{Document Version}

Accepted author manuscript

Link to publication record in Manchester Research Explorer

\section{Citation for published version (APA):}

Mylan, J. (2019). Rage Against the Regime: Niche-regime interactions in the societal embedding of plant-based milk. Environmental Innovation and Societal Transitions. https://doi.org/10.1016/j.eist.2018.11.001

\section{Published in:}

Environmental Innovation and Societal Transitions

\section{Citing this paper}

Please note that where the full-text provided on Manchester Research Explorer is the Author Accepted Manuscript or Proof version this may differ from the final Published version. If citing, it is advised that you check and use the publisher's definitive version.

\section{General rights}

Copyright and moral rights for the publications made accessible in the Research Explorer are retained by the authors and/or other copyright owners and it is a condition of accessing publications that users recognise and abide by the legal requirements associated with these rights.

\section{Takedown policy}

If you believe that this document breaches copyright please refer to the University of Manchester's Takedown Procedures [http://man.ac.uk/04Y6Bo] or contact uml.scholarlycommunications@manchester.ac.uk providing relevant details, so we can investigate your claim.

\section{OPEN ACCESS}




\title{
Rage Against the Regime: \\ Niche-regime interactions in the societal embedding of plant-based milk
}

Author accepted manuscript for publication in Environmental Innovation and Societal Transitions

\begin{abstract}
This paper engages with the debate on niche-regime interactions in sustainability transitions, using a study of plant-based milk and its struggles against the entrenched liquid dairy-milk regime, which has various sustainability problems. Plant-based milk is understudied, so our empirical contribution consists of an exploration of its diffusion in the UK. We make three conceptual contributions. The first calls for a bidirectional analysis that addresses niche-oriented activities by incumbent actors, in addition to the outwardoriented activities by niche advocates presented in most studies of niche-regime interaction. The second contribution nuances Smith and Raven's fit-and-conform and stretch-andtransform typology: using a societal embedding framework which distinguishes four environments, we suggest that hybrid patterns are possible in which innovations follow a 'fit' pattern in one environment but 'stretch' in another. The third contribution highlights the potential role of cultural meanings in galvanizing transitions by eroding positive associations that support the regime and stabilise consumer purchasing.
\end{abstract}

\section{Keywords}

Sustainability transitions; milk; liquid dairy milk; diffusion; niche-regime interaction

Authors: Josephine Mylan ${ }^{1}$, Carol Morris ${ }^{2}$, Emma Beech $^{3}$, and Frank W. Geels ${ }^{4}$

${ }^{1}$ Sustainable Consumption Institute and Manchester Institute of Innovation Research University of Manchester, 188 Waterloo Place, Oxford Road, Manchester M13 9PL Josephine.mylan@manchester.ac.uk

Corresponding author

${ }^{2}$ School of Geography, University of Nottingham; Carol.Morris@nottingham.ac.uk

${ }^{3}$ School of Geography, University of Nottingham; emma.m.b@live.co.uk

${ }^{4}$ Sustainable Consumption Institute and Manchester Institute of Innovation Research; University of Manchester, UK; frank.geels@manchester.ac.uk 


\section{Introduction}

Food has received relatively less attention in the sustainability transitions community than energy or mobility (Markard, 2017). This is somewhat surprising since Agriculture, Forestry and Other Land Use (AFOLU) are responsible for $24 \%$ of global greenhouse gas emissions (IPCC, 2014). The United Nations estimates that livestock and intensive animal husbandry accounts for $18 \%$ of global GHG emissions ${ }^{1}$ as well as substantially contributing to water pollution and land degradation (UNFAO, 2006). High consumption of meat and dairy also correlates with the occurrence of heart disease and obesity, while livestock production has long been the target of animal protection activism (Miele, 2011). The (over)production and consumption of food derived from animals is therefore increasingly identified as a crucial sustainability problem (Westhoek et al., 2014). In light of these issues multiple groups (including climate scientists, health professionals, and civil society activists) exert pressures on the animal-centric food system, mobilising arguments spanning issues of environment, health and animal protection.

Conceptually, the relative neglect also means that analytical frameworks and transition typologies, which have mostly been developed and tested with case studies in electricity and mobility, may require some adjustment for applications to sustainability transitions in food (see also Sutherland et al., 2014). We suggest that the cultural considerations influencing consumption, for instance, are likely to play a larger role in food transitions (Fourat and Lepiller, 2017) than in electricity, where many empirical studies looked at supply-side electricity generation. Furthermore, the particular kind of structure found in food systems, in which primary producers (thousands of farmers) are separated from end consumers (millions of households) by concentrated food-processing and retail corporations, is known to shape the diffusion of innovation (Mylan et al., 2015). This 'hourglass' structure concentrates power among a few large food system actors who occupy an intermediary position between primary production and final consumption (Carolan, 2016; Lang et al., 2009). These large intermediary incumbent actors are also less locked-in to upstream technological production regimes when compared to electricity or transport, and consequently have more flexibility to switch to alternatives if they see strategic opportunities. The 'socio-technical regime' (Geels, 2004) is thus more dispersed and less monolithic in food than in other domains.

Using an in-depth case study of plant-based milk (PBM), which refers to milk produced from soy, nuts, legumes, seeds and grains, the paper aims to make several contributions to sustainability transitions debates. The first contribution is empirical, drawing attention not only to sustainable food in general, but also to an unfolding transition in milk, where PBM is struggling against an entrenched animal-based dairy regime. This contribution is relevant from a sustainability angle, because beef and dairy are two sectors with large environmental impacts, as noted above. While social scientists have begun to address meat and 'de-meatification' (Dagevos and Voordouw, 2013; Morris et al., 2014; Vinnari and Vinnari, 2014; Emel and Neo, 2015; Morris, 2018; Mylan, 2018), there has so far been less attention for dairy milk and plant-based alternatives. The paper thus breaks

\footnotetext{
${ }^{1}$ These emissions are not just from animals directly (e.g. methane from enteric fermentation and nitrous oxide emissions from manure), but also relate to feed production (e.g. deforestation for pasture and feed crops, chemical fertilizer production, feed transport) and transport of animal products (e.g. beef, milk).
} 
empirically new terrain. Although PBM may have different inputs, it can be considered as a green niche-innovation, firstly because it provides a substitute for dairy-milk and, secondly, because the various PBM product categories face many similar struggles against the liquid dairy-milk regime.

The paper also aims to make three conceptual contributions, engaging particularly with the Multi-Level Perspective (Geels, 2004; 2011) and the debate on niche-regime interactions, which is gaining momentum in this journal and beyond (Bui et al., 2016; Diaz et al., 2013; Ingram, 2015, 2018; Smith and Raven, 2012; Hess, 2016; Raven et al., 2016). The three contributions, which section 2 positions in the ongoing debate, concern: bi-directional niche-regime interactions; more varied fit-stretch patterns (Smith and Raven, 2012) across different environments for the societal embedding of innovations; the role of cultural criticism and protest ('rage') in destabilizing existing regimes.

The paper is structured as follows. Section 2 elaborates our conceptual contributions by positioning them in the debate on niche-regime interactions. Section 3 discusses caseselection, provides some initial information about PBM development and diffusion, and describes the methods used to generate primary and secondary data. Section 4 presents the PBM case, addressing interactions between the PBM niche and the liquid dairy-milk regime in the UK on four dimensions: user preferences and markets, industry, cultural debate, and policy. Section 5 analyses the case with a focus on our conceptual contributions. Section 6 draws conclusion.

\section{Niche-regime interactions in societal embedding for sustainability transition}

A key insight from the field of sustainability transitions is the recognition that existing arrangements of production and consumption play a central role in shaping how new, more sustainable configurations emerge and take hold. Much of the theoretical work in this area has been developed within the framework of the 'Multi-Level Perspective', which conceptualises transitions as emerging from interactions between processes at different 'levels' of niche, regime and landscape (Rip and Kemp, 1998; Geels, 2002, 2011). Radical innovations initially emerge in technological niches, which act as protected spaces for nurturing and learning processes (Smith and Raven, 2012). These radical innovations face uphill struggles against entrenched regimes where processes operate to maintain the status quo or restrict change to established trajectories. The concept of the 'socio-technical regime' has its roots in the 'technological regime' (Nelson and Winter, 1982), but was subsequently elaborated to capture the multiple social, political and cultural domains through which established routines, interests and investments are reproduced, working to maintain stability and constrain innovation. Geels (2004) distinguished six key dimensions of the socio-technical regime (industry, user preferences, scientific knowledge, culture, policy, and technology), each with associated institutions, actors, and resources that explain dynamic stability and unfolding trajectories in societal functions such as food provisioning. Further, each dimension acts to exert selection pressures on the niche-innovations, with consequences for how they develop and become embedded in society (Smith and Raven, 2012).

Many empirical studies have shown the roles of learning processes, social network building, visions, and intermediary actors (Kemp et al., 1998; Geels and Raven, 2006; Van der Laak et al., 2007; Schot and Geels, 2008; Temmes et al., 2013) in the emergence of 
radical niche-innovations, often with case studies from the electricity and mobility domains, e.g. solar-PV, wind turbines, electric cars, or biofuels.

Subsequent studies have started to address diffusion, investigating how radical innovations can "escape their protective spaces" (Smith and Raven, 2012: 1026). This shift towards later phases also implied two shifts in analytical focus: a) from technological niches to market niches and b) from niche-internal processes (e.g. learning, network building) towards interactions with existing regimes, which led to debates about niche-regime interaction. Smith (2007) identified 'translation' as an important process through which elements of niche-innovations are selectively appropriated into established regimes. Smith suggested that mildly reforming niche-elements (such as products) could be relatively unproblematically appropriated, while more radical niche-elements (such as cultural meanings or lifestyles) often remain confined to sheltered spaces, where they are pursued by committed actors with limited interest from incumbents.

Smith and Raven (2012) further emphasised the importance of niche 'empowerment', which may result from externally-oriented activities through which niche advocates aim to change rules and selection criteria in socio-technical regimes.

Empowerment is an inherently political and negotiated process involving the building of coalitions and the deployment of narratives that justify policy change. They proposed two ideal-type empowerment patterns in niche-regime interactions: 'fit-and-conform', in which niche-innovations diffuse because they fit in with the existing selection environment, and 'stretch-and-transform', in which niche-innovations diffuse because advocates succeed in transforming existing regimes.

The empowerment-approach privileges the perspective of niche advocates and thus adopts a 'bottom-up' or niche-to-regime view on change. This unidirectional approach is also present in other recent work on niche-regime interactions. Diaz et al. (2013), for instance, focus on networking activities by niche actors to enrol regime actors with more resources. Ingram $(2015 ; 2018)$ focuses on knowledge flows from niche-innovations into regimes (via certification, standardization, networking, learning, and frame linkage). Furthermore Hess (2016) suggests that niche-organisations can mobilise against resistant regimes by forming coalitions with political parties, gaining support from incumbent actors in other regimes, and forming coalitions with social movements.

As our first conceptual contribution, we therefore propose a more symmetrical and bidirectional niche-regime analysis, which addresses not only niche-to-regime processes (e.g. 'translation' or 'empowerment'), but also regime-to-niche dynamics. Incumbent firms, for instance, can actively engage with niche-innovations and support their development and diffusion (as supermarkets and food companies do in the PBM-case). As our second conceptual contribution, we aim to nuance Smith and Raven's (2012) niche empowerment typology by suggesting the possibility of 'hybrid' pathways that combine elements of both fit-and-conform and stretch-and-transform. The underlying rationale for this contribution is that we conceptualise diffusion as a process of societal embedding (Deuten et al., 1997; Geels and Johnson, 2018) in which new products need to find their place in four pre-existing environments (Figure 1$)^{2}$. In each of these environments diffusion entails struggles between niche-innovations and associated actors on the one hand and incumbent actors and

\footnotetext{
${ }^{2}$ These environments (of new products or technologies) resonate with the dimensions of sociotechnical regimes (Geels, 2004). Only 'scientific knowledge' is not included in this representation, which is unproblematic for our focus on diffusion.
} 
institutions on the other hand. Because niche-regime interactions play out differently in different environments, we expect that a fit-and-conform pattern may occur in some environments (e.g. PBM being disseminated through existing businesses and retail chains), while a stretch-and-transform pattern may occur in others (e.g. cultural meanings of milk being fundamentally challenged). Rather than a single 'fit' or 'stretch' pattern, we therefore propose that hybrid patterns are possible.

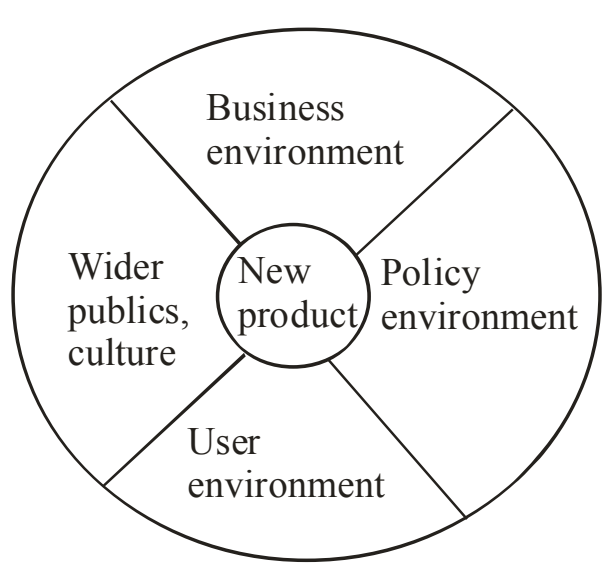

Figure 1: Relevant environments for new products and practices (adapted from Deuten et al., 1997: 134)

Our third conceptual contribution is to suggest that the cultural dimension is likely to play an important, even leading, role in sustainable food transitions. The reason is that food and eating are deeply entwined with activities and cultural conventions of everyday life (Warde, 2016). Negative debates about environmental, health or other aspects of food products are therefore likely to strike a chord with the wider public. These normative contestations, which we figuratively refer to as 'rage against the regime ${ }^{3}$, may erode and destabilise the cultural legitimacy of existing regimes (Elzen et al., 2011; Roberts, 2017). Additionally, cultural debates may stimulate niche development (Geels and Verhees, 2011), because positive meanings may attract attention and influence consumer purchasing. The wider implication is that sustainability transition pathways do not have to start with technical innovations, as much of the niche literature suggests, but can also begin with cultural mobilisation and protest.

\section{Methods}

Using the PBM case, we will provide empirical illustrations for these conceptual contributions. We selected plant-based milk (PBM) as a case study for two reasons. First, it is understudied, as most empirical studies of transitions away from animal-related products focus on meat and 'de-meatification' (Dagevos and Voordouw 2013; Weis 2013; Morris et al., 2014; Emel and Neo 2015; Dagevos 2016; Morris 2018). While the article thus breaks new empirical ground, our aim is not to provide the definitive analysis of PBM. Instead, we aim to explore this topic, while also intending to make conceptual contributions to transition debates. Second, although PBM has long remained confined to ethical and medical (i.e.

\footnotetext{
${ }^{3}$ This figurative phrase, which we also use in the paper's title, references the 1990 s rock band 'Rage Against the Machine', which was known for its revolutionary political views.
} 
lactose-intolerance) market niches, it has begun to diffuse since around 2005, as we will further show below, reaching global market shares comparable to 12\% of dairy-milk in 2017 (data from Euromonitor quoted in Guardian Online, 2018b). This means the case is suitable to investigate early diffusion and societal embedding, and to address our conceptual contributions with regard to niche-regime interaction. Although our analysis focuses on the UK, which has seen rapid PBM-diffusion in the past two decades, we situate this in relation to other (Western) countries in order to emphasise that this is not a UK specific phenomenon.

The case study was developed through several rounds of research, as insights emerged and the associated narratives where identified and interpreted. As such, the case study does not represent a definitive account of the diffusion of PBM, but rather highlights interesting dynamics with relevance for our focus on the interactions between the PBM niche and the liquid dairy milk regime.

The first round of research involved analysis of 109 secondary documents, which took place during June and July 2016 (see Appendix 1 for details). Since PBM-diffusion is relatively new and under-studied, there is a paucity of academic sources on the topic. We therefore identified secondary sources online using a number of predefined search terms in Google including 'non-dairy milk', 'plant milk', 'plant drink', continuing the search until all relevant documents and organisations was judged to have been reached. While recognising that 'any search engine provides access to only a portion of the Web' (Bryman, 2012: 655) the accuracy of Google as a search engine has been established by earlier studies of this matter (Thelwall, 2008; Weaver and Bimber, 2008). The following kinds of secondary sources were used to gather information about the four different environments, across a range of sources including market and commercial reports, news media, blogs, and PBM product websites.

- For markets and user preferences, we used data from national research organisations such as Mintel and Euromonitor.

- To collect data about the business environment, we looked at PBM company reports and websites, as well as reporting in the business press (e.g. Bloomberg, Financial Times). - For the cultural environment, we collected data from newspapers, NGO reports and public campaigns.

- For the policy environment, we investigated policy reports (e.g. on nutritional and dietary guidelines), legal battles (e.g. on product definitions) that were reported in the media, and interest group reports (e.g. from the UK's Dairy All Parliamentary Group).

A full list of the sources used to generate an initial account of the dynamics in each of the four environments is presented in Appendix 1.

The second round of research consisted of a small number $(\mathrm{N}=6)$ of semi-structured expert interviews with a range of UK stakeholders in the PBM niche, including commercial actors in the PBM industry, advocates for plant-based diets (e.g. vegan and vegetarian organisations), environmental groups and nutrition experts. Interviews were recorded and transcribed in full. Interviews took place following the initial documentary analysis (between August and October 2016) and served several purposes: 1) to elicit responses to the emerging insights from the documentary analysis - enabling identification of alternative views and tensions across different aspects of the account, which could be further explored; 2) to 'fact check' data and trends identified from the secondary analysis; 3 ) to deepen the emerging narrative; and 4) to identify further useful sources of information which had not been previously identified. 
The third round of research aimed to strengthen the understanding of key dynamics within the 'cultural' environment, supplementing insights from the documentary analysis of UK-based public campaigns, newspaper articles and NGO reports with a deeper analysis of the relationship between PBM products and consumers. This was approached in two ways. The first was via a material-discursive analysis of the claims and information offered on PBM packaging which included all 13 brands of PBM available for consumer purchase in the UK. The second entailed a group interview (focus group) with 6 UK consumers, in which the knowledge and ideas of PBM, with particular reference to PBM marketing, product packaging, and public campaigns related to dairy and PBM consumption were explored. While this single focus group cannot be considered representative of the opinions of the wider UK population it was instructive in relation to the range of issues and experiences considered important by consumers with reference to the relationship between PBM and liquid dairy milk on multiple dimensions. While these data are not presented in full in the paper, they did contribute to identifying key dynamics in relation to the cultural significance of PBM developed in the case study.

The texts, including documents from the first round analysis and those generated through expert interview, focus group and product packaging analysis, were coded, compared against one another and then re-coded to formalise the identification and development of themes (Ryan and Bernard, 2003), including the identification of repetition, similarity, difference and contradiction (Bryman, 2015). Data were then organised and interpreted according to our analytical categories (niche-regime interactions in four environments).

The fourth round of data collection, which took place during September-December 2017, served to update market data and further explore themes which emerged during the analysis and development of the case study text. The data generated at this stage were not formally coded, but used to add narrative depth to assist in the communication of key insights from the case study.

The next section describes the research results, which are organized along the four environments for niche-regime interaction. For each environment, we first describe PBM niche dynamics (including regime-oriented actions) and then the liquid dairy-milk regime (including niche-oriented actions). Since policies are oriented towards the other environments, our description of the policy environment follows a different logic, focusing on substantive policy areas that shape business and consumption (namely primary production, market regulation, and nutritional guidelines).

\section{Niche and regime dynamics in the societal embedding of plant-based milk (2000-2016)}

While PBM in the form of soya milk has a long history in China, it was not produced on a commercial scale in the United States or Europe until the 1950s. In the US, Dr. Harry Miller pioneered soya milk as a healthier alternative to dairy-milk, which was also environmentally and ethically sound (Shurtleff and Aoyagi, 2013). In the UK, PBM was developed by Arthur Ling, who created The Plant Milk Society in the mid-1950s as a branch of the Vegan Society. For decades, PBM remained confined to the small niche of 'ethical' consumers (e.g. vegans) and people with lactose intolerance, and was produced by small-scale, specialist organizations. During this period, attention focused on technical issues (e.g. improvements in the palatability and appearance of soya milk; developing specialized machinery) and the sourcing of appropriate and affordable ingredients (Mather, 1986). Consumer demand 
remained very low, however, as Ling himself noted: "the major problem was to demonstrate the need for an alternative to dairy milk. We had therefore a double act to perform: of educating as well as selling" (cited in Mather, 1986). This double act was not easy, because PBM was up against powerful actors in the mainstream liquid dairy-milk regime (farmers, state-sponsored nutritional agencies and the agricultural lobby) which after the Second World War had constructed dairy milk as an iconic healthy food that was vital to good nutrition (Wiley, 2011). Campaigns such as drink-a-pint-a-milk-a-day had established dairy-milk as a taken for granted healthy product (Dupuis, 2002).

Since the mid-2000s, however, PBM has broken out of small ethical and medical niches, becoming more mainstream. Market research data indicates that in $201712 \%$ of global milk sales to consumers fall under the category of 'plant-based-milk' (Euromonitor quoted in Guardian Online, 2018). The following sections describe the process of societal embedding by addressing dynamics in the PBM-niche and the liquid dairy-milk regime across four 'environments': users/markets, business, culture and policy.

\subsection{Market dynamics and revealed consumer preferences}

\section{$P B M$ niche}

The PBM market in the UK remained relatively small until around 2005, but then expanded, accelerating particularly after 2010: PBM-sales reportedly grew by $40 \%$ in three years, between 2011 and 2013, increasing from 36 to 92 million liters in that period (DairyCo market research quoted in Guardian Online, 2014). This growth reflects the pattern of PBM market expansion across Western Europe as whole (which can be seen in Figure 2).

Compared to liquid dairy-milk products, the market share (in terms of retail value sales) of PBM reached $5 \%$ in the UK in 2016. This is currently less than in the US (at 11\%), Belgium (9\%) France and Spain (8\%) and the Netherlands (7\%), but higher than Ireland (4\%) and Finland (2\%) (data from Euromonitor). Market research undertaken in 2015 indicated that $18 \%$ of UK consumers report using PBM, a figure which had risen from $11 \%$ in 2013 (Mintel, 2017). Both the overall market share and the relatively high proportion of consumers using PBM demonstrates that it has moved beyond small niches, and is becoming mainstream in the UK.

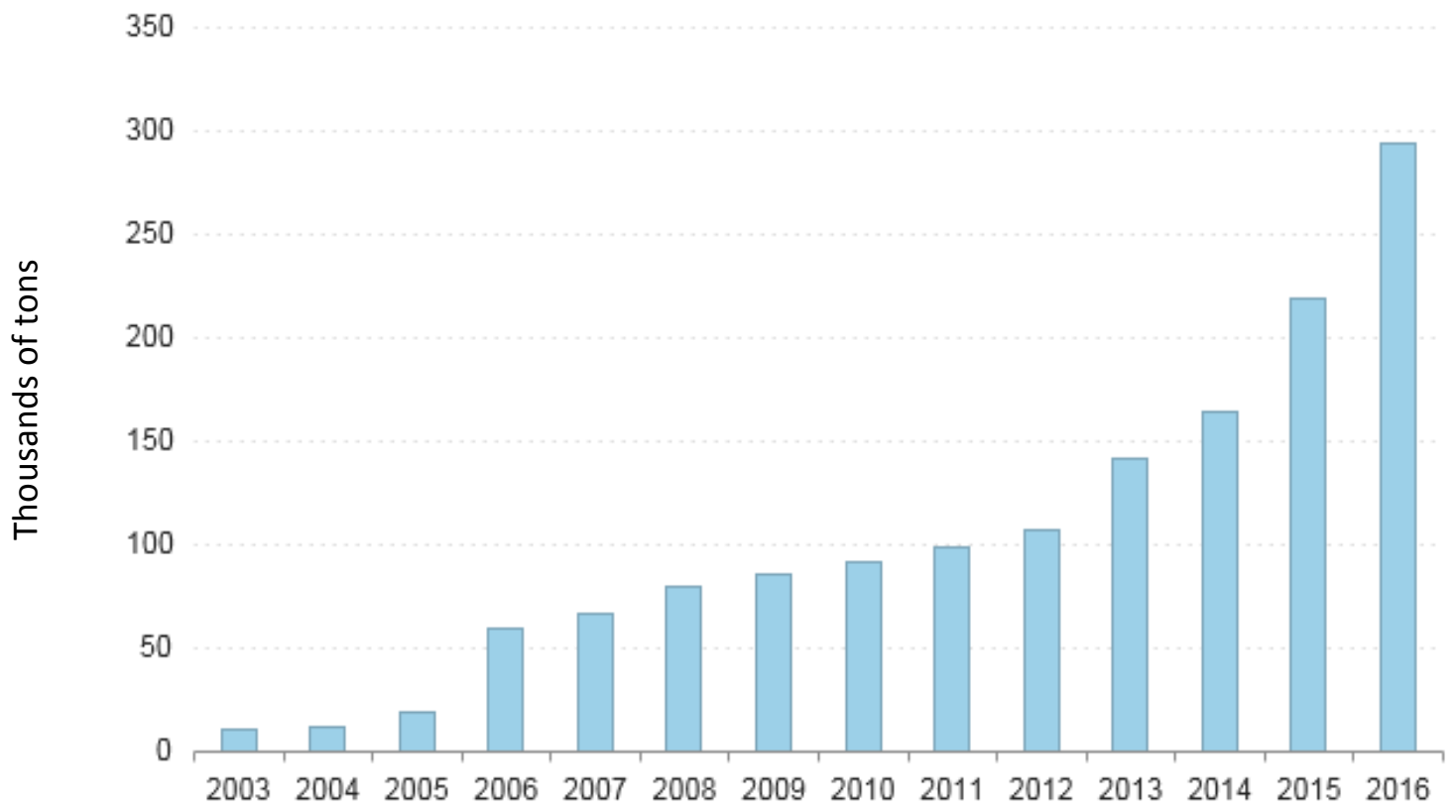


Figure 2: Expanding markets of plant-based milk in Western Europe (based on data from Euromonitor; last accessed 18 December, 2017)

While both the UK and the wider European markets for dairy-milk alternatives continue to grow rapidly, they are still lagging behind North America, where sales grow by $9 \%$ per year, having reached a total market value of $\$ 1.9 \mathrm{bn}$ in 2015 (Mintel 2016). Market research data (Mintel 2017; Market and Markets, 2015) suggests that in the UK, traditional motivations for consuming PBM (such as lactose intolerance and milk allergy) are being complemented by a wider range of considerations, such as health issues (e.g. 'heart health') and 'lifestyle' motivations (e.g. weight loss, animal welfare). The latter also include more radical preferences for veganism and the 'clean living' movement, promoting plant-based eating (Janssen et al., 2016; Radnitz, et al., 2015). PBM-consumption seems to be particularly associated with younger age groups (Mintel, 2017). Another indication of consumer mainstreaming is that in 2017 milk-type drinks became one of the products in the 'typical' shopping basket of food items used to calculate the rate of inflation in the UK economy (Financial Times Online, 2017). While soy milks traditionally dominate PBM consumption by volume, but there has been rising interest in milk from cereals (rice, oats, barley), nuts (almonds, hazelnuts, walnuts, coconut) and seeds (hemp) (Mintel, 2017). In the UK this trend has been at least partly attributed to growing consumer awareness of the adverse environmental consequence of large scale soy production (Mintel, 2017).

Market research indicates that most PBM-consumers use PBM alongside dairy-milk, which means that the transition from dairy milk to PBM presently has complementary or 'add-on' characteristics (which is a pattern that has also been found for some historical transitions, e.g. Geels, 2002). 98\% of UK households report having dairy products in their fridges, alongside simultaneous increases in PBM consumption (Mintel, 2017). This pattern is reflected in the U.S. which has consumed higher volumes of PBM over a longer period $69 \%$ of PBM-consumers report interchangeably consuming dairy milk and PBM (Mintel, 2016).

Liquid dairy-milk regime

Meanwhile, the existing liquid dairy-milk regime is facing a long-term decline in per capita consumption in the UK, alongside a shift away from full fat milk consumption towards skimmed and semi-skimmed products. Although this decline (represented in Figure 3 below) began before the rise of PBM, it helps explain why dairy producers see PBM as an additional threat. 


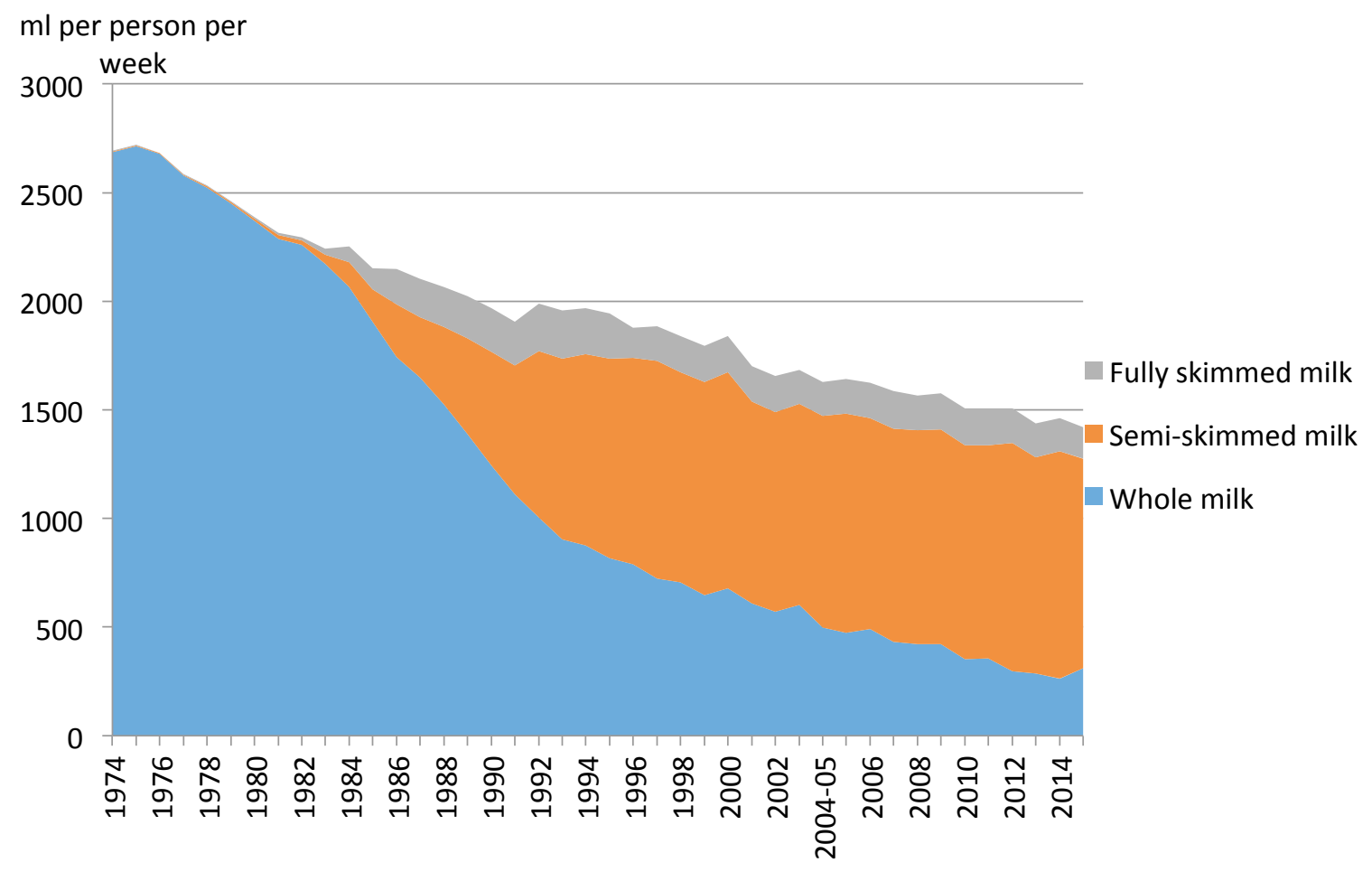

Figure 3: Average UK milk consumption 1973-2015 (data from DEFRA, 2017)

One contributing factor is a shift in meal patterns, particularly the decline in breakfast consumption and the use of dairy-milk on breakfast cereal. Another factor is that 'sodas' are increasingly preferred over dairy-milk beverages (Markets and Markets, 2015). Thirdly, the taken-for-granted image of dairy-milk as iconic healthy food, which has been nurtured for decades by the dairy-milk industry and state agencies, is eroding. Criticisms by scientists and various NGOs (further discussed below under 'culture') have created doubts about the health and environmental implications of dairy milk. In the UK younger people in particular, are less likely to consume dairy-milk (Mintel, 2016).

\subsection{Business: Technical improvements, marketing strategies and acquisitions PBM niche}

PBM producers (which include Almond Breeze, Alpro, Ades, Hebei, Oatly, Provamel, Silk, Vitasoy and White Wave) have stimulated the diffusion of dairy alternatives by developing and refining production technologies and positioning PBMs in relation to dairy-milk.

Producers eliminated the 'beany' taste, which was previously associated with soya milk, helping to align it more closely with the experience of drinking dairy-milk (Shurtleff and Aoyagi, 2013). Packaging developments (e.g. using Tetrapack aseptic packaging technology) helped to expand market possibilities by extending its shelf life, while also making the appearance of PBM-products more similar to dairy milk. Product innovation and marketing thus followed a 'fit' strategy, which aimed to make the radical innovation look less different from the existing regime to generate feelings of familiarity (Hargadon and Douglas, 2001; Smith and Raven, 2012).

PBM producers also marketed PBMs as positive alternatives to dairy-milk, using health claims on packaging, in promotional materials and on their websites. PBMs are positioned as a healthier alternative to dairy-milk - variously presented as being lower in 
fats, sugars and calories. The oat milk manufacturer Oatly (2016), for instance, claims that

"...where people continue to struggle to meet dietary recommendations for saturated fats and fibre, oats may be a welcome addition for those trying to improve their diet". Most PBM producers also make claims about greater environmental sustainability, frequently in comparison to dairy milk. For example, Alpro, the UKs top selling brand, asserts on its packaging that their products are "good for you and good for the planet" using "... less land and water and produce less $\mathrm{CO}_{2}$ than dairy milk", while Oatly claims its production leads to "two thirds less $\mathrm{CO}_{2}$ being emitted than dairy milk".

PBM producers also engaged in diversification strategies, moving from soy towards other primary ingredients (e.g. legumes, seeds, nuts or grains). They also diversified in terms of product brands and product characteristics, e.g. (un)sweetened, flavoured, pasteurised or ultra-high temperature treatment. In 2014, plain, unsweetened PBMs, which most closely resemble dairy milk, still constituted the largest PBM market (Market and Markets, 2015). But new product launches mainly concern new offerings distinguished by "different flavors, packaging, and fortified products with calcium and vitamin $D$ to enhance their nutritional value" (Market and Markets, 2015). This product diversification also indicates that firms and marketers consider the growing PBM-market to be lucrative, not least because PBM on average sells for more than twice the price of dairy-milk (Financial Times Online, 2017).

\section{Liquid dairy-milk regime}

Responses by incumbent actors in the liquid dairy-milk regime vary. The defensive activities of UK dairy farmers should be understood in the context of long-term structural changes in the industry such as a decline in the number of UK dairy farms and cow numbers (Figure 4), alongside an increase in average herd size, and a rise in the proportion of milk produced by farms producing over 1 million litres annually (DairyCo, 2013). These structural changes, combined with pressure from declining milk consumption, fluctuating milk prices, and cattle diseases (Davies, 2015) have contributed to a context in which dairy farmers feel under threat from the potential of PBM to replace liquid milk, leading to defensive responses. A Welsh Milk board member for instance, was reported in the national UK media claiming that vegan activists present "an extremist view of dairy milk farming which portrays a completely inaccurate image of the UK dairy industry" and calling for the dairy industry to increase the promotion of their produce (Welsh Milk Board quoted in Guardian Online, 2017c). Similar defensive activities occurred in other countries. The Dairy Lobby in Sweden (LRF Mjölk), responded through legal channels, taking Oatly to court in 2014 over its claims that dairy milk was unhealthy (Gustafsson, 2015). This defensive strategy backfired, however, because the ensuing media attention raised public awareness about the debate. The controversy reportedly boosted Oatly's sales in Sweden by 45\% (Gustafsson, 2015). 


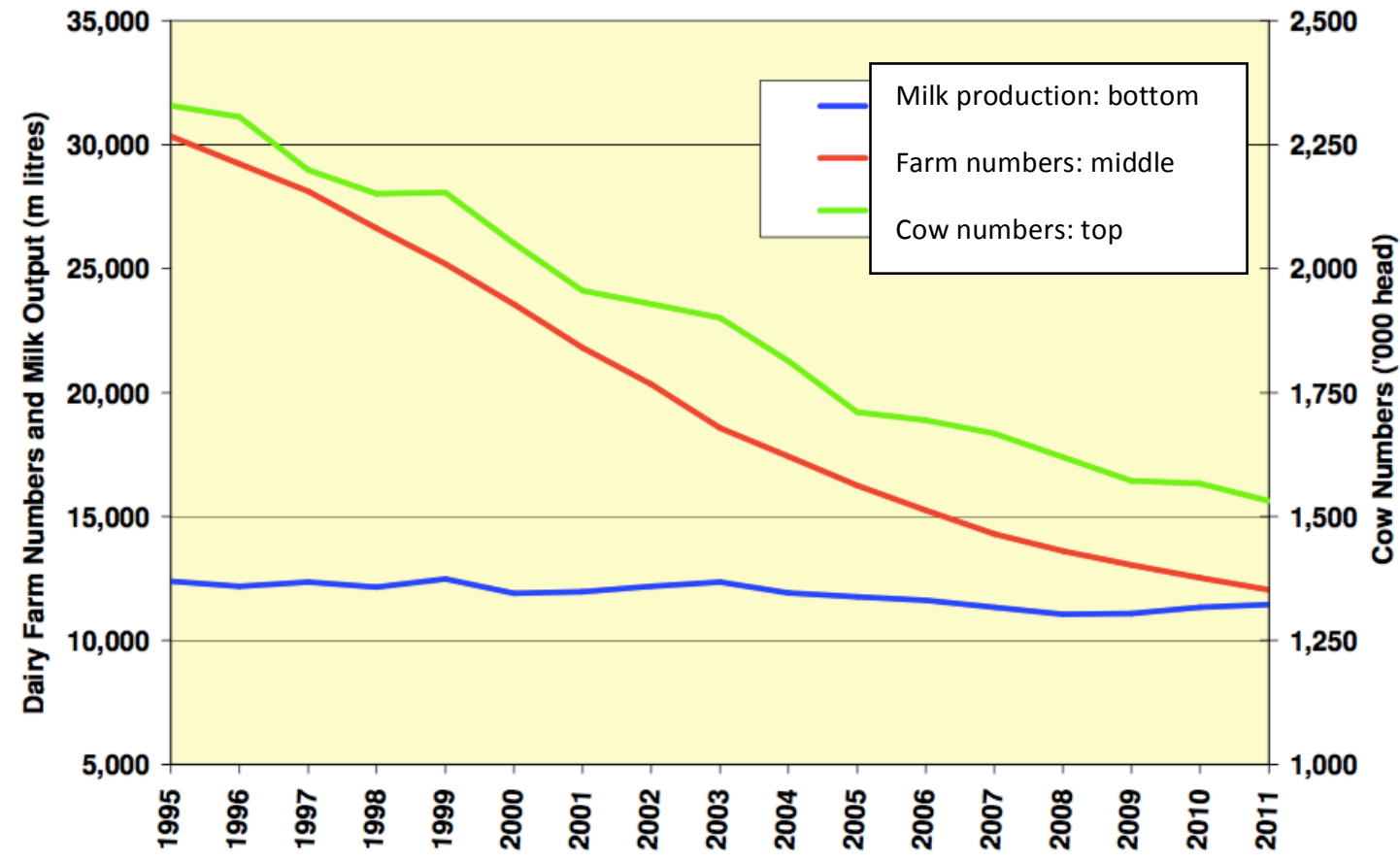

Figure 4: Trends in the UK dairy sector 1995-2011 data from DairyCo, Defra and RPA. Source: DairyCo 2013

In response to criticisms, the liquid dairy milk industry has also responded with incremental improvement strategies such as changes in management practices (e.g. more efficient feeding regimes), new breeding technologies, 'agro-ecological' production methods and their associated technological and organisational innovations (Mylan et al., 2015). These improvements aim to defend the existing liquid dairy-milk regime.

Supermarkets, which are a powerful liquid dairy-milk regime incumbent (responsible for over $80 \%$ of dairy milk sales in the UK), have been willing to partially diversify towards PBM, which greatly supported the incorporation of PBMs into mainstream food provisioning. The reason is that supermarkets are consumer-facing organisations that are less invested in primary production, and mainly mediate between producers and consumers. As demand for PBM grew, supermarkets started to engage with this emerging market. By making valuable shelf space available for PBM products, they also helped to mainstream the product and stimulate demand. Supermarkets positioned PBM in fridges alongside dairy-milk equivalents, which further served to reinforce the perceived similarities between PBMs and dairy-milk. Supermarkets have also started to supply 'own-label' PBMs alongside more expensive branded products. Supermarket own-label products not only increased availability and affordability of PBMs, but also reinforced their status as an everyday mainstream product.

Food processing companies, another powerful regime incumbent, also have begun to diversify towards PBM, adding financial resources and organizational capabilities to the niche. The multinational dairy company Danone, for instance, acquired two European PBM producers (Alpro and Provamel) and recently also purchased US-based PBM producer White Wave for $\$ 12.5 b n$ (Financial Times Online, 2016). While Danone is a dairy multinational, it is first and foremost a consumer goods company. It is not vertically integrated to the agricultural stage of production, and therefore has less interest in maintaining dairy production in light of shifting demand. Its purchase of PBM brands signals the perceived importance of PBM markets and helps in further mainstreaming. Attracted by its potential, 
other food and drink companies also moved into the PBM-sector (Financial Times Online, 2017). Coca-Cola recently bought Ades, the biggest soya-based drink in Latin America, while Nestlé acquired a $60 \%$ stake in Yinlu, the world's fifth-largest plant-alternative group.

\subsection{Cultural significance: Civil society campaigns and public debate}

\section{PBM niche}

Civil society organisations including the Plant Milk Society and the Vegan Society have promoted positive meanings of PBM since the 1950s, although often as part of radical visions of plant-based eating (Leneman, 1999; The Vegan Society, 2014). Producers have also framed PBM as healthy, environmentally friendly, and fitting with modern lifestyles (as indicated in section 4.1), using advertisements, websites and public statements.

NGOs also support the PBM-niche by engaging in sustained attacks that aim to disrupt the established meanings of dairy-milk as healthy, nutritious and natural. These public campaigns initially highlighted environmental and animal welfare problems, but in recent years additionally focused on health dimensions. We also note some specialization, in the sense that public campaigns against animal-sourced foods have been complemented by milk-focused campaigns in recent years.

Environmental problems associated with animal agriculture, including climate change, water pollution and land degradation, have long been highlighted by environmental NGOs, scientists and public agencies. 'The global benefits of eating less meat' report (Gold, 2004), by the animal welfare NGO Compassion in World Farming, was an important early contribution to the debate about the socio-environmental problems of animal-sourced foods. The 2006 United Nations report 'Livestock's long shadow: Environmental issues and options' was a major milestone in environmental criticisms of the meat and dairy industry. The 2010 campaign 'Healthy Planet Eating' (2010) by Friends of the Earth also linked livestock production to various environmental problems, concluding that reduced consumption of animal-sourced foods is necessary for a sustainable food system. It also suggests that dairy intake needs to be lowered to reduce strokes, cancer, obesity and premature death. The Vegan Society also emphasizes the unsustainability of dairy production, arguing that a significant shift away from animal sourced foods is required if the UK is to meet its climate change targets (Vegan Society website, visited June 2016).

Attacks have long focused on animal protection and the cruelty of dairy milk farming, particularly in the UK, where Harrison's 1964 book Animal Machines galvanized the animal protection movement: Compassion in World Farming was created in 1967, the Animal Liberation Front in 1976, and PETA (People for the Ethical Treatment of Animals) in 1980. These NGOs initially campaigned against general farming practices and conditions (e.g. overcrowded stables, use of veal crates, pigs on concrete floors, un-sedated castration), but some also started focusing on milk production. In 2017, the campaign group Go Vegan World sponsored newspaper adverts that stated that 'humane milk is a myth: don't buy it'. This campaign criticized the practice of removing calves from cows shortly after birth. The UK dairy milk lobby complained to the Advertising Standards Authority (ASA) that the advert was 'inaccurate and misleading' by suggesting that dairy milk farms were not complying with animal welfare standards (DairyCo UK quoted in Guardian Online, 2017a). The ASA rejected the claim, however, ruling that the advert was not materially misleading consumers.

The health claims of dairy milk have also been criticized in recent years, feeding into a growing uncertainty about the healthfulness of dairy milk among consumers (Mintel, 
2016). The 2014 'White lies' campaign by the animal rights group Viva! attacked the industry's claims that milk is healthy and nutritious. Drawing on peer-reviewed articles, their report suggests that dairy milk is, in fact, implicated in many diseases, including allergies, arthritis, some cancers, and coronary heart disease. PETA's 2014 'Ditch dairy' campaign also attacked milk's health claims, linking dairy consumption and autism. It also portrayed dairy milk consumption as 'unnatural' since only humans consume milk across species.

Some NGOs also try to discredit dairy-milk production on economic grounds. PETA (2016), for instance, urged large UK dairy producers to move out of dairy-milk production and into crops such as soy, which it argued were economically more profitable. The UK Vegan Society's “Grow green" report (The Vegan Society, 2015) also presents PBMs as a viable commercial alternative for farmers, which simultaneously helps to tackle climate change. Their report suggested that dairy farmers should grow hemp or fava beans instead of producing dairy-milk.

The increase in civil society campaigns and criticisms does not imply that a complete shift in cultural understandings has already happened. It does indicate, however, that takenfor-granted positive meanings of milk and animal source food more generally are under pressure. Indeed, a wider societal debate has been gaining momentum in the last few decades around meat production and consumption (Emel and Neo, 2015; Morris, 2018). Concerns about climate change have galvanised a variety of actors (including from science, the private sector and civil society) in criticising the over-production and consumption of animal source foods, particularly meat and dairy, because of their contribution to greenhouse gas emissions. One prominent response is the establishment of a range of mostly civil society organised 'Less meat initiatives' (Morris et al., 2014; Singer, 2016) which have raised the level of public debate about meat consumption. Analysis of the reporting of the Meat Free Monday campaign in the UK's print news media since 2009 revealed that this is more likely than not to be positive in tone suggesting a shift in societal relationships with animal source foods and meat in particular (Morris, 2018).

\section{Liquid dairy-milk regime}

The animal source food industry challenges and rejects many of the criticisms or claims made against it with the dairy-milk industry already taking action to address problems, e.g. through (incremental) innovations, as noted above. It also defends itself more aggressively through formal complaints to the UK Advertising Standards Authority (noted above) and through legal actions (as Oatly case, discussed in section 4.2). These active defenses indicate that the dairy lobby is concerned, and views the mounting criticisms as threats that warrant a response. Nevertheless, the liquid dairy milk regime is still stabilised to some degree by long-standing cultural discourses. In response to adverse health claims, the industry body DairyCo UK can still confidently state that dairy-milk is "a consistent consumer favourite with well-known nutritional benefits and an essential part of a healthy diet" (DairyCo UK quoted in Guardian Online, 2014). PBM-advocates also agree that this narrative continues to reflect widespread understandings. As a Vegetarian Society representative observed when interviewed: "a number of GPs think a vegetarian diet is unhealthy.... (F)or plant milk that could be problem. People do the old-fashioned thing, to fall back on milk as a health food" (Interview with The Vegetarian Society, 2016). 
Although the liquid dairy-milk regime is not (yet) collapsing, the pressures exerted toward de-legitimising dairy consumption and production, by raising concerns over health environmental, and ethical implications, have stimulated the societal acceptance of PBMs and influenced purchasing. Although more radical NGO narratives (which encourage wholesale shifts towards plant-based eating lifestyles) have arguably had less widespread traction, they have generated impact in terms of media, consumer and regulatory attention. The recent substantial and rapid increase in the reported adoption of veganism in the UK ${ }^{4}$, together with an associated shift in news media reporting (see for example Guardian, 2018) away from its anti-vegan or 'vegaphobic' emphasis less than a decade ago (Cole and Morgan, 2011) provide further evidence. As such, we suggest that the observed 'rage against the regime' has contributed to destabilising the taken-for-granted positive characteristics of liquid dairy-milk by questioning narratives of naturalness and health.

\subsection{Policy: Primary production, market regulation and nutritional guidelines}

Although PBM emerged without dedicated policy support, its further diffusion and societal embedding are influenced by government policies and formal institutions. The degree of hindrance or accommodation varies across primary production, market regulation, and nutritional guidelines.

\section{Primary production}

Agricultural policy overwhelmingly aims to support (and incrementally reform) the liquid dairy milk regime, and has shown little interest in the PBM niche. The sustainability of agricultural policies has been criticised by many organisations, including Vegetarian and Vegan Societies, environmental NGOS, and animal protection NGOs. These organisations also called for policies that would stimulate a shift toward plant-based eating. For instance, the 2015 "Grow Green" report by the Vegan Society calls for policy reforms in the wider food system and the need for a "multi-sector approach and the cooperative work of different bodies and governmental departments" (The Vegan Society, 2015: 6). Pointedly, the report emphasises the need for action to "reduce dependency on livestock" which, it is claimed, public policy and environmental NGOs have failed to achieve. However, since these actors are mostly outsiders to the policymaking process, their criticisms and suggestions have had limited direct effects. Our interviewees acknowledged that government support to encourage less consumption of dairy milk was low to non-existent attributing this in part to the government's vested interests in maintaining the existing liquid dairy milk regime.

\section{Market regulation}

Policymakers also played a role in struggles about market regulation through product definitions. In response to perceived threats, the beleaguered dairy milk industry has started contesting the use of the 'milk' label by PBM producers, arguing that only liquid secretion from mammary glands of mammals can be called 'milk'. In the United States, this legal battle already started in 2000, when the National Milk Producers Federation complained to the Food and Drugs Administration about soymilk producers using the milk label (FDA, 2000). US policymakers are currently debating legislation which would limit the

\footnotetext{
${ }^{4}$ Research for the Vegan Society (2015), for example, suggests that the number of vegans in the UK increased from 150,000 to 542,000 between 2006 and 2016 (a rise of 350\%), representing over 1\% of the UK's population.
} 
use of the term 'milk' to products derived from animals (Shilton, 2017). Similar battles in the UK led the Food Standards Agency to introduce regulations in 2010, which required that only liquid from animals could be called milk. PBM producers responded by attempting to circumvent these rules using terms such as ' $m y l k$ ' ' $m$ * $l k^{\prime}$ " and 'malk' to qualify and market their products. The European Dairy Association, in turn, escalated the battle to the European Court of Justice, which in June 2017 reinforced the legal difference between liquid dairy milk and plant-based alternatives, and reserved use of the milk label for the former (Guardian, 2017b). Incumbent actors thus attempt to use market regulations and product labelling to hinder the diffusion of PBM and, so far, it appears that policymakers and lawyers are sympathetic to their case.

\section{Nutritional guidelines}

A third policy area concerns the production of national dietary guidelines, which sanction particular principles (e.g. eat more fibre) and position particular products, such as PBM, in relation to these. These guidelines are negotiated between professionals from nutritional sciences, public health and the food industry. In the UK, one important tool to communicate a healthy diet to citizens is the 'Eat Well Guide' produced by Public Health England. Support for dairy consumption in this guide has been declining, with the most recent version recommending $50 \%$ less calories from dairy foods compared to the previous edition (Dairy UK, 2016; Eatwell Guidelines, quoted in The Metro, 2016). Although the guide does not say that PBMs should replace dairy, it does acknowledge that PBMs can form part of a healthy diet. This means that PBM is, to some extent, being translated into formal institutions of the food and dietary regime.

This development is contested by incumbent actors such as the UK's Dairy All Parliamentary Group (DAPG), which provides a forum for parliamentarians to discuss issues of interest for the dairy industry. The DAPG recently issued a report 'Putting Dairy Back on the Daily Menu' (DAPG, 2016), which recommended to the Department of Health that it should implement a 3-a-day programme for dairy, to encourage the consumption of milk and dairy products as part of a healthy and balanced diet. It acknowledges that there has been recently "a small surge of plant-based alternatives to dairy, most of them boasting of a better nutritional, environmental and economic impact than dairy foods". But it concludes that "upon closer examination, it seems that dairy fares better than its alternatives" (DAPG, 2016: 9).

Similar dietary guidance struggles occurred in the United States, which led national nutrition guidance to advocate increased consumption of dairy milk for protein and calcium intake. This change was in the wake of the 'Get Real' campaign, set up in 2015 to support the US dairy industry by responding to health criticisms of milk. In this case the National Dairy Council together with Milk Processor Education Program and Dairy Management Inc. lobbied the US health department for changes in nutritional guidance in response to negative health claims published in academic literature (US Department of Health and Human Services and US Department of Agriculture, 2015). These examples indicate that state-sanctioned nutritional guidance is an important battleground, which incumbent actors can use to retain market share and resist change.

The above descriptions suggest that niche-regime interactions in the policy environment have unfolded differently within production (agriculture), marketing (product definitions) and consumption (nutritional and dietary guidelines). In production and marketing, policymakers mostly align with incumbents to support the dairy milk regime; in 
consumption, there is some movement to accommodate PBM in formal institutions, although this clearly varies between countries.

\section{Analysis}

The case clearly shows that the societal embedding of PBM occurred across several environments, including users, industry, culture and policy. The early diffusion of PBM is well underway, as evidenced by their use by mainstream consumers; sale by branded producers; diversification by supermarkets and food-service companies; and (some) statesanctioning through nutritional guidance. With regard to niche-regime interactions, we draw the following three lessons from the case.

First, in all four environments, relevant dynamics occurred at niche and regime levels, which confirms the importance of bi-directional analyses of niche-regime interactions. While PBM producers and advocates clearly tried to exert 'upward' influence on the liquid dairy-milk regime, there were also instances of some 'downward' engagement by regime actors with the niche-innovation, especially in the business environment. While PBM has long existed in small market niches of dedicated proponents, the diversification of incumbent actors (namely those in intermediary positions between consumers and primary producers) was crucial for wider mainstreaming. Supermarkets, coffee shop chains, and branded processors (such as Danone, Nestlé and Coca-Cola) were important in making nondairy replacements consistently available and 'normalising' them for mass consumption.

We suggest that this relatively unproblematic engagement of incumbent industry actors with the PBM-niche is due to the specific 'hour-glass' structure of food provision, in which multiple commercial actors operate at a distance and the relationship between primary producers and consumers is mediated by a small number of very large firms (in retailing and food processing). Farmers and their representatives, which are key actors in maintaining the liquid dairy milk regime, operate with a different set of interests and investments than either retailers or branded-food producers, which buy their milk but are primarily concerned with maintaining existing or cultivating new consumer goods markets. This provisioning structure provides the conditions for multiple, distinct (but connected), selection environments within which innovations must become established, in order for wider system change to occur. Since retailers and food processors have limited sunk investments in upstream dairy production, they are less locked-in to the liquid dairy-milk regime, which makes it easier to shift towards PBM as consumer markets expand.

Second, changes in cultural significance were a crucial driver in this unfolding transition. Persistent and increasing NGO criticism and negative public debates challenged the taken-for-granted positive meanings that stabilised the liquid dairy-milk regime, providing opportunity for the diffusion and societal embedding of PBMs. Changes in cultural significance associated with the consumption of animal-derived foods also triggered consumer interest in PBM, which, in turn, stimulated responses from producers and retailers via process improvements, product diversification and marketing. Public health officials implemented some changes in dietary guidance, which followed rather than led cultural changes and shifting consumption patterns. However, policymakers did not lead PBM-diffusion, and in some instances actively hindered it, because they mostly aligned with dairy-milk incumbents (e.g. in product labelling and agricultural support). This sequence suggests that cultural changes were crucial for PBM-diffusion by eroding the liquid dairymilk regime and by contributing to the legitimacy of shifts in consumers' general orientation 
toward animal and plant-based foods. The case thus forms an interesting counter point to existing niche-analyses, which often emphasise the role of 'technology advocates' as key actors in outward oriented socio-political work.

Third, the societal embedding of PBM is characterised by a pattern which incorporates key elements from both the ideal-types of niche-regime interactions proposed by Smith and Raven (2012). Both the 'fit-and-conform' (F\&C) and 'stretch-and-transform' (S\&T) patterns suggest that niche-innovations diffuse by either aligning with the existing selection environment ( $F \& C$ ) or acting upon and altering the selection environment (S\&T). In the case of PBM we observe both processes at work in different selection environments. Although Smith and Raven (2012) acknowledge multi-dimensionality, their empirical focus on (upstream) renewable electricity generation leads them to privilege market selection, which is shaped by policies, which are influenced by discursive struggles. Our analysis of PBM-diffusion, in contrast, provides a more differentiated view of niche-regime interactions, in which the interactions unfolded differently in the four environments. In the cultural environment we saw sustained pressure on the status quo, some of which arose from radical campaigns, which we figuratively characterise as 'rage'. Repeated criticisms and negative public campaigns contributed to undermining the positive meanings that had long stabilised dairy-milk. In Smith and Raven's typology, this can be characterised as 'transformation' of cultural meanings. However, in the market and business environment, this was arguably followed by product-oriented reform activities, where change was limited to replacement of one product (dairy-milk) by another (PBM) in otherwise unchanged retail and user practices.

Radical critiques and significant adjustments in the orientation of consumers toward the idea of animal-based food as central to healthy diets have thus been followed by a relatively incremental reform trajectory. Based on this analysis, we suggest that PBM diffusion followed a hybrid 'rage-and-reform' pattern, in which sustained and polarising cultural protests eroded the meanings of the existing regime, and were followed by product-oriented reform activities led by commercial actors. This outcome differs from the radical orientations and visions of some social movements, which envisaged complete reorientation of diets away from animal products (e.g. veganism) and radical changes in technologies and organisation of agriculture (e.g. a move from dairying to the cultivation and processing of crops such as fava beans and hemp). This hybrid pattern (which includes both radical and reforming elements) may not be an exception, as it seems to resonate with Smith's (2007) analysis of organic food, which was also selectively appropriated into the mainstream food system.

\section{Conclusion}

Using the case of plant-based milk, the paper has made an empirical contribution to the sustainability transitions literature, drawing attention to the agro-food domain, which is important in terms of sustainability and interesting conceptually, because of systemic and structural specificities, compared to energy and mobility. Using these specificities, the paper also made three empirically-supported contributions to the debate on niche-regime interactions. First, the current focus on outward-oriented activities by niche advocates needs to be extended to a bi-directional analysis that also accommodates regime-to-niche mechanisms. Second, transitions may follow hybrid 'fit' and 'stretch' patterns, because incremental reform and more substantial transformation may play out differently across 
and between multiple environments. Third, sustainable food transitions inevitably entail an important role for consumers and cultural processes. This means that the actions of consumers, citizens, or 'users' become central to the progress of sustainable food transitions through their role in mediating between changes in the various regime environments. Activities within 'policy', and 'industry' unfold as attempts to interpret and shape food consumption, while cultural entrepreneurs (such as NGOs) engage directly with attempting to re-orient citizen-consumers' ethical positions. Sustainability transitions in food may thus be specific because of the role of food consumption in everyday meaning making and the structure of food provisioning.

Future research could further explore these findings by analysing how different characteristics of food, energy and mobility systems influence transition patterns. Such research could investigate how the relative importance of the four environments and associated causal mechanisms varies across empirical domains, countries and innovations. With regard to the user environment, we further recommend that future transition research probes more deeply into actual consumer behaviour, investigating how consumers appropriate new products and use them in various practices. Our research was somewhat limited in that respect, focusing mainly on market dynamics and revealed consumer preferences.

\section{References}

Bryman, A., 2015. Social research methods, Oxford University Press, Oxford. Bryman, A., 2012. Social research methods, fourth ed. Oxford University Press, Oxford. Bui, S., Cardona, A., Lamine, C., Cerf, M., 2016. Sustainability transitions: Insights on processes of niche-regime interaction and regime reconfiguration in agri-food systems. Journal of Rural Studies, 48, 92-103.

Carolan, M., 2016. The sociology of food and agriculture, second ed. Routledge Earthscan, London and New York.

Cole, M., Morgan, K., 2011. Vegaphobia: derogatory discourses of veganism and the reproduction of speciesism in UK national newspapers. Sociology, 62 (1), 134-153. DairyCo, 2013. The structure of the GB dairy farming industry: What drives change? Report produced by the Andersons Centre on behalf of DairyCo.

Dairy UK, 2016. Dairy UK update. Dairy APPG 'Sorely disappointed' by dairy reduction in Eatwell Guide. http://www.dairyuk.org/mediaarea/press-releases/item/dairy-uk-updatedairy-appg-sorely-disappointed-by-dairy (accessed 11 December 2016).

Dairy All-Party Parliamentary Group (DAPG), 2016. Putting dairy back on the menu. Dairy All-Party Parliamentary Group: London.

Dagevos, H., 2016. Exploring flexitarianism: meat reduction in a meat-centred food culture, in: Raphaely, T., Marinova, D. (Eds.), Impact of meat consumption on health and environmental sustainability, IGI Global, Hershey, PA.

Dagevos, H., Voordouw, J., 2013. Sustainability and meat consumption: Is reduction realistic?. Sustainability: Science, Practice, \& Policy, 9, 60-69.

Davies. I., 2015. MPs sign motion calling for fair milk price for farmers.

http://www.fwi.co.uk/livestock/ (accessed 1 August 2015).

DEFRA, 2017. Family Foods 2015, Department for Environment, Food and Rural Affairs, London.

Deuten, J.J., Rip, A., Jelsma, J., 1997. Societal embedding and product creation management. Technology Analysis \& Strategic Management, 9 (2), 131-148. 
Diaz, M., Darnhofer, I., Darrot, C., Beuret, J-E., 2013. Green tides in Brittany: What can we learn about niche-regime interactions?. Environmental Innovation and Societal Transitions, 8, 62-75.

Dupuis, M., 2002. Nature's perfect food: how milk became America's drink, NYUP: New York.

Emel, J., Neo, H., (Eds.) 2015. Political ecologies of meat, Routledge, Abingdon.

Elzen, B., Geels, F.W., Leeuwis, C., Van Mierlo, B., 2011. Normative contestation in transitions 'in the making': Animal welfare concerns and system innovation in pig husbandry (1970-2008). Research Policy, 40 (2), 263-275.

Financial Times Online, 2016. Danone agrees $\$ 12.5 \mathrm{bn}$ deal for health-focused WhiteWave Foods Acquisition is French yoghurt maker's biggest in a decade. https://www.ft.com/content/9ab78f12-43db-11e6-9b66-0712b3873ae1 (accessed 21 August 2017).

Financial Times Online, 2017. Dairy shows intolerance to plant-based competitors. https://manchester.idm.oclc.org/login?url=https://search.proquest.com/docview/1928265 146? accountid=12253 (accessed 1 September 2017).

Food and Drug Administration (FDA), 2000. Soyfoods of North America Association. http://www.fda.gov/ohrms/dockets/dailys/00/apr00/041700/c000012.pdf (accessed 30 November 2016).

Fourat, E., Lepiller, O., 2017. Forms of Food Transition: Sociocultural Factors Limiting the Diets' Animalisation in France and India. Sociologia Ruralis, 57 (1), 41-63.

Friends of the Earth (FOE), 2010. Healthy Planet Eating: How lower meat diets can save lives and the planet, Friends of the Earth: London.

Geels, F.W., 2002. Technological transitions as evolutionary reconfiguration processes: a multi-level perspective and a case-study. Research Policy, 31 (8-9), 1257-1274.

Geels, F.W., 2004. From sectoral systems of innovation to socio-technical systems: Insights about dynamics and change from sociology and institutional theory. Research Policy, 33 (6),897-920.

Geels, F., 2011. The multi-level perspective on sustainability transitions: Responses to seven criticisms. Environmental Innovation and Societal Transitions, 1 (1), 24-40.

Geels, F.W., Johnson, V., 2018. Towards a modular and temporal understanding of system diffusion: Adoption models and socio-technical theories applied to Austrian biomass districtheating (1979-2013). Energy Research and Social Science, 38, 138-153.

Geels, F.W., Raven, R.P.J.M., 2006. Non-linearity and expectations in niche-development trajectories: Ups and downs in Dutch biogas development (1973-2003). Technology Analysis \& Strategic Management, 18 (3/4), 375-392.

Geels, F.W., Verhees, B., 2011. Cultural legitimacy and framing struggles in innovation journeys: A cultural-performative perspective and a case study of Dutch nuclear energy (1945-1986). Technological Forecasting \& Social Change, 78 (6), 910-930.

Gold, M., 2004. The global benefits of eating less meat. Report compiled for Compassion in World Farming, Petersfield, Hampshire.

Guardian online, 2014. 'Make mine a quinoa cappuccino' the unstoppable rise of the milk substitutes.

https://www.theguardian.com/lifeandstyle/wordofmouth/2014/mar/10/quinoacappuccino-soy-almond-oat-milk-dairy-alternatives (accessed 30 March 2017). 
Guardian online, 2017a. Humane milk is a myth: veganism advert cleared by standards body. https://www.theguardian.com/lifeandstyle/2017/jul/26/humane-milk-is-a-mythveganism-advert-cleared-by-standards-body (accessed 18 August 2017).

Guardian online, 2017b. Dairy wars: When is a glass of milk really a glass of $\mathrm{m}^{*}$ ilk. https://www.theguardian.com/lifeandstyle/shortcuts/2017/jul/23/dairy-milk-court-animalplant-nut (accessed 18 August 2017).

Guardian online, 2017c. 'Welsh farmers raise concerns over rise in veganism. http://www.bbc.co.uk/news/uk-wales-41713987 (accessed 1 December 2017).

Guardian online, 2018. The unstoppable rise of veganism. https://www.theguardian.com/lifeandstyle/2018/apr/01/vegans-are-coming-millennialshealth-climate-change-animal-welfare (accessed 18 May 2018).

Guardian online, 2018b. Why everything you know about sustainable eating is probably wrong. https://www.theguardian.com/food/2018/sep/05/ditch-the-almond-milkwhy-everything-you-know-about-sustainable-eating-is-probably-wrong (accessed 5 September 2018).

Gustafsson, K., 2015. Oatly Riles Big Dairy.

https://www.bloomberg.com/news/articles/2015-05-14/swedish-oat-milkproducerbenefits-from-dairy-industry-lawsuit (accessed 4 December 2016). Hargadon, A.B., Douglas, Y., 2001. When innovations meet institutions: Edison and the design of electric light. Administrative Science Quarterly, 46 (3), 476-501. Harrison, R., 1964. Animal machines: the new factory farming industry, Vincent Stuart Limited, London.

Hess, D.J., 2016. The politics of niche-regime conflicts: Distributed solar energy in the United States. Environmental Innovation and Societal Transitions, 19, 42-50.

Ingram, J., 2015. Framing niche-regime linkage as adaptation: an analysis of learning and innovation networks for sustainable agriculture across Europe. Journal of Rural Studies, 40, 59-75.

Ingram, J., 2018. Agricultural transition: Niche and regime knowledge systems' boundary dynamics. Environmental Innovation and Societal Transitions, 26, 117-135.

IPCC, 2014. Climate Change 2014: Synthesis Report. Contribution of Working Groups I, II and III to the Fifth Assessment Report of the Intergovernmental Panel on Climate Change. IPCC, Geneva, Switzerland.

Janssen, M., Busch, C., Rödiger, M., Hamm, U., 2016. Motives of consumers following a vegan diet and their attitudes towards animal agriculture. Appetite, 105, 643-651.

Kemp, R., Schot, J., Hoogma, R., 1998. Regime shifts to sustainability through processes of niche formation: the approach of strategic niche management. Technology Analysis \& Strategic Management, 10, 175-195.

Lang, T., Barling, D., Caraher, M., 2009. Food Policy: Integrating Health, Environment and Society, Oxford University Press, Oxford.

Leneman, L., 1999. No animal food. The rise of Veganism in Britain 1909-1944. Society and Animals 7 (3), 219-228.

Markard, J., 2017, Sustainability transitions: guidance and reflections, Keynote talk for the newcomers session at the $8^{\text {th }}$ International Conference on Sustainability Transitions, Gothenburg, 18 June 2017.

Markets and Markets, 2015, Dairy alternative (beverage) market by type, channel and geography - global trends and forecast to 2018, Market Publishers Ltd, United States. 
Mather, H., 1986, Vegan Views 37 - The Milk of Human Kindness.

http://www.veganviews.org.uk/vv37/vv37arthurling.html (accessed 17 November 2016).

The Metro, 2016. Halve your dairy intake to avoid obesity government warns.

http://metro.co.uk/2016/03/26/ (accessed 30 March 2017).

Miele, M., 2011. The taste of happiness: Free-range chicken. Environment and Planning A, 43, 2076-2090.

Mintel, 2016. US sales of dairy milk turn sour as non-dairy milk sales grow in 2015. http://www.mintel.com/press-centre/food-and-drink/ (accessed 30 March 2017).

Mintel, 2017. Free From Foods - UK - December 2017. Mintel Market Research Ltd. London, UK.

Morris, C., Kirwan, J., Lally, R., 2014. Less meat initiatives: An initial exploration of a dietfocused social innovation in transitions to a more sustainable regime of meat provisioning. International Journal of the Sociology of Agriculture and Food, 21 (2), 189-208.

Morris, C., 2018. 'Taking the politics out of broccoli': debating (de)meatification in UK national and regional newspaper coverage of the Meat Free Mondays campaign. Sociologia Ruralis, 58 (2), 433-452.

Mylan, J., Geels, F.W., Gee, S., McMeekin, A., Foster, C., 2015. Eco-innovation and retailers in milk, beef and bread chains: enriching environmental supply chain management with insights from innovation studies. Journal of Cleaner Production, 107, 20-30 Mylan, J., 2018. Sustainable Consumption in Everyday Life: A Qualitative Study of UK Consumer Experiences of Meat Reduction. Sustainability, 10 (7), 2307.

Nelson, R.R., Winter, S.G., 1982. An evolutionary theory of economic change, Harvard University Press, Massachusetts.

Oatly, 2016. The power of Swedish oats. http://www.oatly.com (accessed 17 November 2016).

PETA, 2016. We're urging UK farmers to swap cruel dairy foods for profitable soya milk. http://www.peta.org.uk/blog/urging-uk-farmersswap-cruel-dairy-foods-profitable-soya-mil (accessed 17 November 2016).

Radnitz, C., Beezhold, B. and DiMatteo, J., 2015. Investigation of lifestyle choices of individuals following a vegan diet for health and ethical reasons. Appetite, 90, 31-36.

Raven, R., Kern, F., Verhees, B., Smith, A., 2016. Niche construction and empowerment through socio-political work. A meta-analysis of six low-carbon technology cases.

Environmental Innovation and Societal Transitions, 18, 164-180.

Rip, A., Kemp, R., 1998. Technological change, Human Choice and Climate Change, 2, 327399.

Roberts, C., 2017. Discursive destabilisation of socio-technical regimes: Negative storylines and the decline of the American railroads. Energy Research and Social Science, 31, 86-99. Ryan, G., Bernard, H., 2003. Techniques to Identify Themes. Field Methods, 15 (1): 85-109. Schot, J., Geels, F., 2008. Strategic niche management and sustainable innovation journeys: theory, findings, research agenda, and policy. Technology Analysis \& Strategic Management, 20, 537-554.

Shilton, A.C., 2017. The battle over the word 'milk'.

https://www.outsideonline.com/2152336/should-nut-milk-be-considered-milk?amp

(accessed 21 April 2017).

Shurtleff, W., Aoyagi, A., 2013. History of soymilk and other non-dairy milks (1226-2013), first ed. SoylnfoCenter, California. 
Singer, R., 2016. Neoliberal Backgrounding, the Meatless Monday Campaign, and the Rhetorical Intersections of Food, Nature, and Cultural Identity. Communication, Culture \& Critique, 10 (2), 344-364.

Smith, A., 2007. Translating sustainabilities between green niches and socio-technical regimes. Technology Analysis \& Strategic Management, 19 (4), 427-450.

Smith, A., Raven, R., 2012. What is protective space? Reconsidering niches in transitions to sustainability. Research Policy, 41 (6), 1025-1036.

Sutherland, L., Darnhofer, I., Wilson, G., Zagata, L., 2014. Transition pathways towards sustainability in agriculture: case studies from Europe, CABI Publishing, Wallingford.

Temmes, A., Räsänen, R.-S., Rinkinen, J., Lovio, R., 2013. The emergence of niche protection through policies: The case of electric vehicles field in Finland. Science \& Technology Studies, 26 (3), 37-62.

Thelwall, M., 2008. Quantitative comparisons of search engine results. Journal of the American Society for Information Science and Technology, 59 (11), 1702-1710.

The Vegan Society, 2014. Ripened by human determination: 70 years of the Vegan Society. http://vegansociety.com/sites/default/files/uploads/Ripened\%20by\%20human\%20determi nation.pdf (accessed 5 September 2018).

The Vegan Society, 2015. Grow Green.

http://vegansociety.com/sites/default/files/Grow\%20Green\%20Report\%20201512a\%20we b.pdf (accessed 6 September 2018).

UNFAO, 2006. Livestock's long shadow: Environmental issues and options, United Nations Food and Agriculture Organization, Rome, Italy.

US Department of Health and Human Services, U.S. Department of Agriculture, 2015. 20152020 Dietary Guidelines for Americans, eighth ed.

http://health.gov/dietaryguidelines/2015/guidelines/ (accessed 17 November 2016).

Van der Laak, W., Raven, R.P.J.M., Verbong, G.P.J., 2007. Strategic niche management for biofuels. Analysing past experiment for developing new biofuels policy, Energy Policy, 35 (6), 3213-3225.

Vinnari, M., Vinnari, E., 2014. A framework for sustainability transition: The case of plantbased diets. Journal of Agricultural and Environmental Ethics, 27 (3), 369-396.

Warde, A., 2016. The practice of eating, Polity Press, London.

Weaver, D.A., Bimber, B., 2008. Finding news stories: a comparison of searches using LexiNexis and Google News. Journalism and Mass Communication Quarterly, 85 (3), 515530.

Weis, A., 2013. The meat of the global food crisis. The Journal of Peasant Studies, 40 (1), 6585.

Westhoek, H., Lesschen, J. P., Rood, T., Wagner, S., De Marco, A., Murphy-Bokern, D., Leip, A., van Grinsven, H., Sutton, M. A., Oenema, O., 2014. Food choices, health and environment: Effects of cutting Europe's meat and dairy intake. Global Environmental Change, 26, 196-205.

Wiley, A.S., 2011. Milk for 'growth': global and local meanings of milk consumption in China, India, and the United States. Food and Foodways, 19 (1-2), 11-33. 
Appendix 1: Sources used in documentary analysis

\begin{tabular}{|c|c|c|}
\hline $\begin{array}{l}\text { Conceptual } \\
\text { Category }\end{array}$ & $\begin{array}{l}\text { Document } \\
\text { type }\end{array}$ & Reference \\
\hline \multirow{12}{*}{$\begin{array}{l}\text { Consumers } \\
\text { and } \\
\text { markets }\end{array}$} & $\begin{array}{l}\text { Market } \\
\text { research }\end{array}$ & Mintel (2015) Evolution of the Global Free-From Market \\
\hline & $\begin{array}{l}\text { Market } \\
\text { research }\end{array}$ & $\begin{array}{l}\text { Mintel (2015) US Sales of Dairy milk turn sour as non-dairy milk sales grow in } \\
2015\end{array}$ \\
\hline & $\begin{array}{l}\text { Market } \\
\text { research }\end{array}$ & $\begin{array}{l}\text { Markets and Markets (2013) Dairy Alternative (Beverage) Market by Type, } \\
\text { Channel \& Geography - Global Trends \& Forecast to } 2018\end{array}$ \\
\hline & $\begin{array}{l}\text { Market } \\
\text { research }\end{array}$ & Mintel (2015) Global Food and Drink Trends 2016 \\
\hline & $\begin{array}{l}\text { Market } \\
\text { research }\end{array}$ & $\begin{array}{l}\text { Brand Packaging (2016) Plant-based Beverages: from Milk Substitute to } \\
\text { Lifestyle Product }\end{array}$ \\
\hline & $\begin{array}{l}\text { Market } \\
\text { research }\end{array}$ & ProCon (2010) Lactose Intolerance by Ethnicity and Region - Milk \\
\hline & $\begin{array}{l}\text { Consumer } \\
\text { research }\end{array}$ & NATCEN Social Research (2016) British Social Attitudes \\
\hline & $\begin{array}{l}\text { Consumer } \\
\text { research }\end{array}$ & NATCEN Social Research (2016) British Social Attitudes 33 \\
\hline & $\begin{array}{l}\text { Consumer } \\
\text { research }\end{array}$ & $\begin{array}{l}\text { NATCEN Social Research (2016) British Social Attitudes: Are We Eating Less } \\
\text { Meat?. }\end{array}$ \\
\hline & $\begin{array}{l}\text { Consumer } \\
\text { research }\end{array}$ & Defra (2015) Family Foods 2014 \\
\hline & $\begin{array}{l}\text { Consumer } \\
\text { research }\end{array}$ & $\begin{array}{l}\text { Chatham House: The Royal Institute of International Affairs (2014) Livestock } \\
\text { - Climate Change's Forgotten Sector: Global Public Opinion on Meat and } \\
\text { Dairy Consumption }\end{array}$ \\
\hline & $\begin{array}{l}\text { Consumer } \\
\text { research } \\
\text { report }\end{array}$ & $\begin{array}{l}\text { Chatham House: The Royal Institute of International Affairs (2015) Changing } \\
\text { Climate, Changing Diets Pathways to Lower Meat Consumption }\end{array}$ \\
\hline \multirow[t]{19}{*}{ Industry } & Website & Oatley.com (Oatley) \\
\hline & Website & Alpro.com (Alpro) \\
\hline & Website & Bluediamondalmonds.co.uk (Blue Diamond) \\
\hline & Website & Ecomil.com/en (Ecomil) \\
\hline & Website & Mydairyfreedream.com (Rice Dream) \\
\hline & Website & Goodhempfood.com (Good Hemp) \\
\hline & Website & kaipachafoods.com/ (Kaipacha) \\
\hline & Website & Perfectdayfoods.com (Perfect Day) \\
\hline & Website & Provamel.com/uk (Provamel) \\
\hline & Website & provitamil.com (Provitamil) \\
\hline & Website & rebel-kitchen.com/ (Rebel Kitchen) \\
\hline & Website & ripplefoods.com/ (Ripple Foods) \\
\hline & Website & risoscotti.com (Risso Scotti) \\
\hline & Website & rudehealth.com (Rude Health) \\
\hline & $\begin{array}{l}\text { Corporate } \\
\text { report }\end{array}$ & Dairy Crest PLC Annual Report 2016 \\
\hline & NGO report & $\begin{array}{l}\text { PETA (2016) We're Urging UK Farmers to Swap Cruel Dairy Foods for } \\
\text { Profitable Soya Milk }\end{array}$ \\
\hline & NGO report & PETA (n.d.) 6 Plant-Based Milks That You've Never Heard Of \\
\hline & $\begin{array}{l}\text { Press } \\
\text { release }\end{array}$ & Center for Consumer Freedom (2014) The Nastiest PETA ad ever? \\
\hline & $\begin{array}{l}\text { Industry } \\
\text { association }\end{array}$ & $\begin{array}{l}\text { Plant Based Foods Association (2016) Plant Based Foods Association Argues } \\
\text { Competitive Harm in Brief Filed in Idaho's "Ag-Gag" Law Challenge }\end{array}$ \\
\hline
\end{tabular}




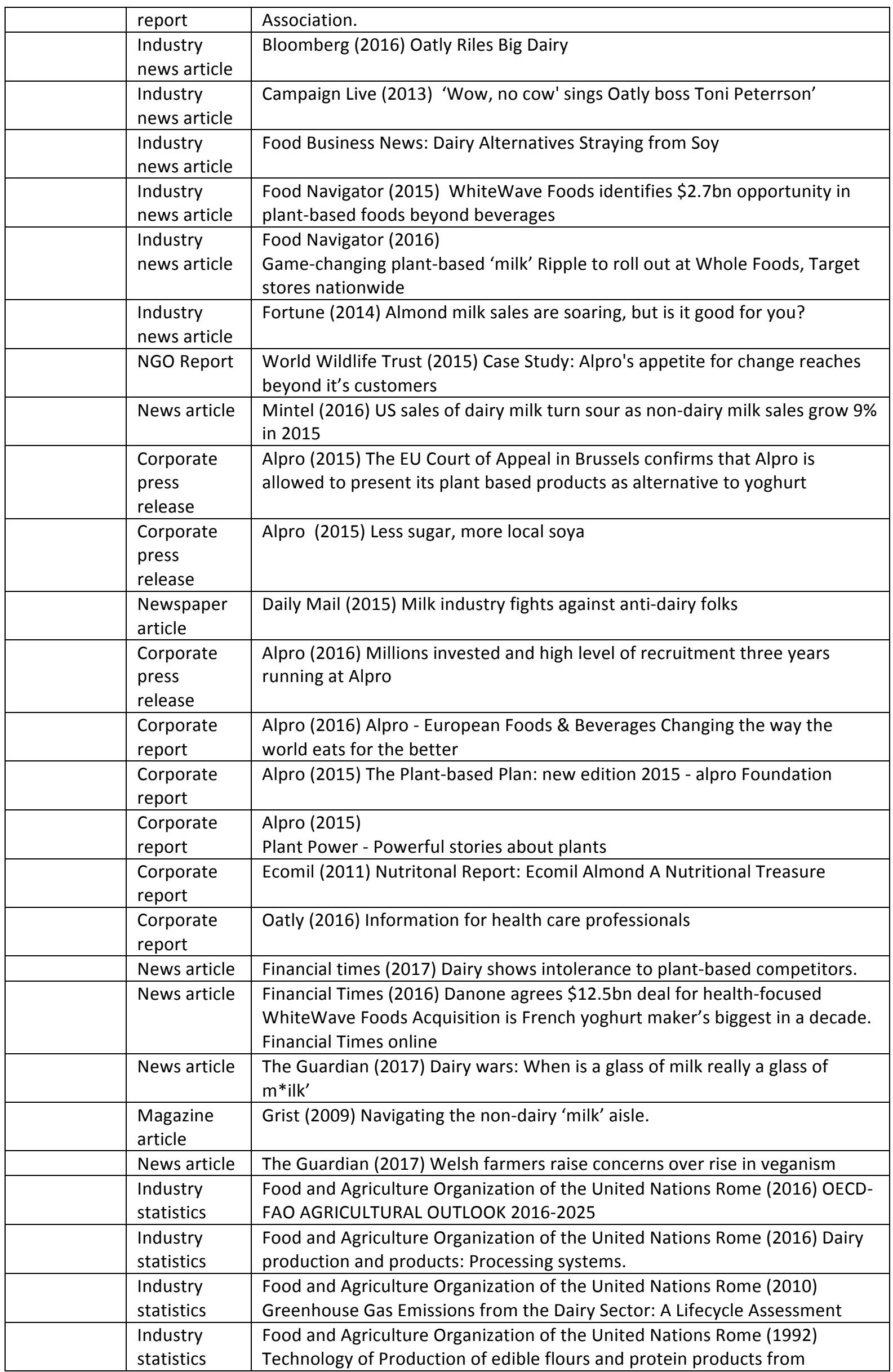




\begin{tabular}{|c|c|c|}
\hline & & soybeans \\
\hline & News article & $\begin{array}{l}\text { The Guardian (2016) Almond milk: quite good for you - very bad for the } \\
\text { planet. }\end{array}$ \\
\hline & News article & $\begin{array}{l}\text { The Telegraph (2017) Hipsters officially go mainstream as gin and soya milk } \\
\text { enter the CPI index }\end{array}$ \\
\hline & News article & Metro (2016) Halve your dairy intake to avoid obesity government warns \\
\hline & News article & $\begin{array}{l}\text { Metro (2016) If we were all vegan, it would save } 8 \text { million human lives a year } \\
\text { - here's why }\end{array}$ \\
\hline & News article & Metro (2016) The best vegan dairy you can find in your local supermarket. \\
\hline & News article & The Independent (2016) Which milk you should drink \\
\hline & News article & $\begin{array}{l}\text { Evening Standard (2014) Another's milk: why Londoners are going nuts for } \\
\text { almond and bean. }\end{array}$ \\
\hline & News article & $\begin{array}{l}\text { Evening Standard (2016) Green is the new black: how veganism became sexy } \\
\text { in London. Evening Standard. }\end{array}$ \\
\hline & News article & $\begin{array}{l}\text { New York Times (2016) Trade Group Lobbying for Plant-Based Foods Takes a } \\
\text { Seat in Washington }\end{array}$ \\
\hline & $\begin{array}{l}\text { Magazine } \\
\text { article }\end{array}$ & $\begin{array}{l}\text { Slate Magazine (2014) Go Ahead, Drink That Almond Milk-It's Not as Bad for } \\
\text { the Environment as Milk }\end{array}$ \\
\hline & $\begin{array}{l}\text { Magazine } \\
\text { article }\end{array}$ & $\begin{array}{l}\text { The Examiner (2014) Examining the environmental impact of plant based } \\
\text { milk alternatives }\end{array}$ \\
\hline & News article & $\begin{array}{l}\text { The Guardian (2017) Humane milk is a myth: veganism advert cleared by } \\
\text { standards body }\end{array}$ \\
\hline \multirow{22}{*}{$\begin{array}{l}\text { Cultural } \\
\text { debates }\end{array}$} & News article & The Guardian (2010) UN urges global move to meat and dairy-free diet \\
\hline & News article & $\begin{array}{l}\text { The Guardian (2014) } \\
\text { UN urges global move to meat and dairy-free diet. }\end{array}$ \\
\hline & News article & The Guardian (2013) Dairy monsters: Just how healthy is milk? \\
\hline & News article & $\begin{array}{l}\text { The Guardian (2016) Animal-free dairy products move a step closer to } \\
\text { market. }\end{array}$ \\
\hline & News article & The Guardian (2016) What's the attitude to vegan food where you live? \\
\hline & Magazine & Vegan.com (n. d.) Vegan Milk \\
\hline & Magazine & Vegan Life Magazine (n.d.) Veganism Booms by $350 \%$. \\
\hline & NGO report & $\begin{array}{l}\text { PETA (2016) We're Urging UK Farmers to Swap Cruel Dairy Foods for } \\
\text { Profitable Soya Milk | PETA UK. }\end{array}$ \\
\hline & NGO report & The Vegan Society (2015) Cows are the real victims of milk price row \\
\hline & NGO report & $\begin{array}{l}\text { The Vegan Society (2015) How the plant-milk movement is currently } \\
\text { triumphing in Sweden }\end{array}$ \\
\hline & NGO report & The Vegan Society (2015) Sweet alternatives to sour milk \\
\hline & NGO report & The Vegan Society (2016) Find out how many vegans are in Great Britain \\
\hline & NGO report & Earthsave (nd) What About Dairy? Looking Behind the Moustache \\
\hline & NGO report & $\begin{array}{l}\text { Friends of the Earth (2010) Healthy Planet Eating: How lower meat diets can } \\
\text { save lives and the planet. }\end{array}$ \\
\hline & NGO report & Friends of the Earth (n.d.) Meat Free May: Post-May Support pack \\
\hline & NGO report & Friends of the Earth (2014) Flexitarianism: the environmentally friendly diet. \\
\hline & NGO report & Friends of the Earth (2002) Local food, future directions. \\
\hline & NGO report & Compassion in world farming (2013) A Diet Fit for World Environment Day? \\
\hline & NGO report & $\begin{array}{l}\text { One Green Planet (2016) Is Your Obsession With Coconuts Harming the } \\
\text { Environment? }\end{array}$ \\
\hline & $\begin{array}{l}\text { Academic } \\
\text { blog }\end{array}$ & $\begin{array}{l}\text { The Conversation (2015) Milking the market: are you pouring additives on } \\
\text { your cereal? }\end{array}$ \\
\hline & $\begin{array}{l}\text { Academic } \\
\text { blog }\end{array}$ & The Conversation (2012) Soy versus dairy: what's the footprint of milk? \\
\hline & Academic & Food Climate Research Network (FCRN) (2016) The Importance of Reducing \\
\hline
\end{tabular}




\begin{tabular}{|c|c|c|}
\hline & report & $\begin{array}{l}\text { Animal Product Consumption and Wasted Food in Mitigating Catastrophic } \\
\text { Climate Change }\end{array}$ \\
\hline & NGO report & $\begin{array}{l}\text { Chatham House: The Royal Institute of International Affairs (2014) Public } \\
\text { largely unaware of how meat and dairy consumption fuel climate change. }\end{array}$ \\
\hline \multirow[t]{18}{*}{ Policy } & $\begin{array}{l}\text { Magazine } \\
\text { article }\end{array}$ & Outside (2015) The battle over the word 'milk' \\
\hline & $\begin{array}{l}\text { Press } \\
\text { release }\end{array}$ & $\begin{array}{l}\text { Dairy UK (n.d.) Dairy APPG 'Sorely Disappointed' by Dairy Reduction in } \\
\text { Eatwell Guide. }\end{array}$ \\
\hline & $\begin{array}{l}\text { Parliamentar } \\
\text { y report }\end{array}$ & Dairy All-Party Parliamentary Group (2016) Putting Dairy Back on the Menu \\
\hline & $\begin{array}{l}\text { Industry } \\
\text { report }\end{array}$ & Dairy Co, Agriculture and Horticulture Board (2012) \\
\hline & $\begin{array}{l}\text { Industry } \\
\text { scientific } \\
\text { report }\end{array}$ & $\begin{array}{l}\text { Dairy Co (2012) Greenhouse gas emissions on British dairy farms. DairyCo } \\
\text { carbon footprinting study: Year one }\end{array}$ \\
\hline & NGO report & $\begin{array}{l}\text { World Wildlife Trust (2011) The Livewell Report: a balance of healthy and } \\
\text { sustainable food choices. }\end{array}$ \\
\hline & NGO report & $\begin{array}{l}\text { Brighter Green (2016) Missing from the Paris Climate Agreement: Any } \\
\text { mention of Industrial Agriculture }\end{array}$ \\
\hline & NGO report & PETA (2015) Veggies Catering Campaign (2013) Non Dairy Milk Veggies \\
\hline & NGO report & PETA (2014) 'Got Autism?' Billboard Gets Pulled \\
\hline & NGO report & PETA (2015) A Vegan's Guide to Non-Dairy Milks \\
\hline & NGO report & $\begin{array}{l}\text { Vegetarian Economy and Green Agriculture (VEGA) (2005) Will EU School } \\
\text { Milk Scheme Include Non-Dairy? }\end{array}$ \\
\hline & $\begin{array}{l}\text { Industry } \\
\text { magazine }\end{array}$ & Farmers Weekly (2015) MPs sign motion calling for fair milk price for farmers \\
\hline & $\begin{array}{l}\text { Research } \\
\text { report }\end{array}$ & $\begin{array}{l}\text { Food and Agriculture Organization of the United Nations Rome (2010) } \\
\text { Sustainable Diets and Biodiversity: DIRECTIONS AND SOLUTIONS }\end{array}$ \\
\hline & NGO report & $\begin{array}{l}\text { Chatham House: The Royal Institute of International Affairs (2016) China } \\
\text { Shows Way with New Diet Guidelines on Meat }\end{array}$ \\
\hline & $\begin{array}{l}\text { Government } \\
\text { report }\end{array}$ & $\begin{array}{l}\text { European Commission: Standing Committee on Agricultural Research (2011) } \\
\text { Sustainable food consumption and production in a resource-constrained } \\
\text { world }\end{array}$ \\
\hline & $\begin{array}{l}\text { Government } \\
\text { report }\end{array}$ & $\begin{array}{l}\text { Public Health England and Food Standards Agency (2016) National Diet and } \\
\text { Nutrition Results from Years 1-4 (combined) of the Rolling Programme } \\
\text { (2008/2009-2011/12). }\end{array}$ \\
\hline & $\begin{array}{l}\text { Government } \\
\text { report }\end{array}$ & $\begin{array}{l}\text { Public Health England (2016) UK and Ireland prevalence and trend: Public } \\
\text { Health England Obesity Knowledge and Intelligence team. }\end{array}$ \\
\hline & $\begin{array}{l}\text { NGO/Gover } \\
\text { nment } \\
\text { report }\end{array}$ & $\begin{array}{l}\text { Sustainable Development Commission (2009) Setting the table: Advice to } \\
\text { Government on priority elements of sustainable diet }\end{array}$ \\
\hline
\end{tabular}

